\title{
THE RELATIONSHIP BETWEEN SOIL HETEROGENEITY AND CELLULOLYTIC ACTIVITY
}

\author{
GALINA ZADOROZHNAYA $\otimes^{1,2}$, KATERINA ANDRUSEVYCH ${ }^{2,3}$ \\ ${ }^{1}$ Department of Biochemistry and Physiology, Oles Honchar Dnipro National University, pr. Gagarina, 72, 49010 Dnipro, Ukraine; e-mail: zadorojhnayagalina@gmail.com \\ ${ }^{2}$ Dnieper-Orilskiy' Nature Reserve, 52030 Obukhovka, Dniprovsk district, Dnipropetrovsk region, Ukraine; e-mail: eandrusevich.311089@gmail.com \\ ${ }^{3}$ Department of Ecology and Technologies of Environmental Protection, National Technical University "Dnipro Polytechnic", pr. Dmitry Yavornitskogo, 19, \\ 49000 Dnipro, Dnipropetrovsk region, Ukraine \\ $\triangle$ Corresponding author
}

Received: 12 May 2019 / Accepted: 30 July 2019

Abstract

Zadorozhnaya G., Andrusevych K.: The relationship between soil heterogeneity and cellulolytic activity. Ekológia (Bratislava), Vol. 40, No. 1, p. 1-7, 2021.

This article examines the relationship between soil heterogeneity and cellulolytic activity. The investigated substrate was a typical chernozem (black soil). Cellulolytic activity was studied by the application method across a regular grid of $7 \times 15$ points $(21 \times 45 \mathrm{~m})$. The distance between the measurement points was $3 \mathrm{~m}$. Soil heterogeneity determined by the measurement of soil penetration resistance using a hand penetrometer Eijkelkamp. Measurements of soil penetration resistance were fixed to a depth of $100 \mathrm{~cm}$ at intervals of $5 \mathrm{~cm}$. Geostatistical analysis showed a high level of spatial dependence of soil cellulolytic activity. Significant correlations were obtained between the spatial distribution of cellulolytic activity and soil penetration resistance at different depths. The results reflect a significant correlation of soil conditions at different depths.

Key words: soil cellulolytic activity, soil heterogeneity, soil penetration resistance, geostatistics.

\section{Introduction}

The study of the spatial relationships of organisms with the environment they inhabit is becoming increasingly popular (Myšák et al., 2013; Kramarenko et al., 2014; Andrusevich, 2014; Andrusevich, Shtirts, 2014; Kunakh et al., 2018). On the one hand, the results of such studies make it possible to establish the spatial patterns of the formation of structures of living communities. On the other hand, they reveal so far unknown features of their environment. The soil is a component of the ecosystem and has a special status. It is both the result of and a necessary condition for the existence of life. The biologically inert nature of the soil and its hierarchical organization distinguish it from the inanimate components of the ecosystem and this confers on soil research its special character.

While studying soil penetration resistance across a regular grid, we found new elements in the soil structure (Zhukov, Zadorozhnaya, 2016). These soil morphological structures extend beyond the genetic horizons' limits and extend to the entire thickness of the soil. Their distribution in space is consistent with changes in environmental conditions and the plant community structure (Zadorozhnaya, Andrusevych, 2018; Zadorozhnaya et al., 2018). New soil elements have been found in all types of natural and technogenic soils that we studied. The dependence of their location on the spatial distribution of the other ecosystem components makes it possible to consider them elementary soil bodies (Zhukov, Zadorozhnaya, 2015). The relationship of these morphological structures with soil organisms (soil biota) is not well understood.

Soil cellulolytic activity is an informatively valuable marker of its biological activity (Zhukov, Lyadskaya, 2009; Tryfanova et al., 2013). Cellulose is an important component of plant tissue. The rate of decomposition of cellulose affects the rate of decomposition of organic matter in general (Swift et al., 1979). The intensity of the cellulose destruction is negatively correlated with the amount of organic matter in the soil. A positive correlation is observed with $\mathrm{pH}$, total phosphorus, iron, potassium, and extractive calcium. There is a significant correlation between the cellulose decomposition rate and the plant growth rate (Latter, Harrison, 1988).

The objective of this work was to clarify the relationship between the spatial location of the out-of-horizon soil morphological structures (ecological relations between the soil body structure) and the biological activity of black soil in terms of cellulolytic activity.

\section{Material and methods}

The test site is located in a steppe area adjacent to the southeastern slope of the Kamenistaya Gully (southern outskirts of the city of Dnipro, Ukraine), $48^{\circ} 38^{\prime} 67^{\prime \prime} \mathrm{N}, 35^{\circ} 09^{\prime} 05^{\prime \prime} \mathrm{E}$. The material was collected in June 2016. The test sites are a regular grid of

(c) The Author(s) 2021. This is an open access article distributed under the terms of the CC BY-NC-ND license.

https://content.sciendo.com/view/journals/eko/eko-overview.xml 
Table 1. Statistical characteristics of the cellulolytic activity of black soil.

\begin{tabular}{|l|c|c|c|c|c|c|}
\hline \multirow{2}{*}{ Cellulolytic activity } & \multirow{2}{*}{ Average value } & \multirow{2}{*}{ Median } & \multirow{2}{*}{ Minimum } & \multirow{2}{*}{ Maximum } & \multicolumn{2}{c|}{ Confidence interval } \\
\cline { 4 - 8 } & & & & & $\mathbf{- 9 5 \%} \%$ & $\mathbf{+ 9 5} \%$ \\
\hline Initial data & 1.27 & 1.32 & 0.51 & 2.01 & 1.20 & 1.33 \\
\hline Logit transformed data & 0.77 & 0.76 & 0.63 & 0.91 & 0.76 & 0.78 \\
\hline
\end{tabular}

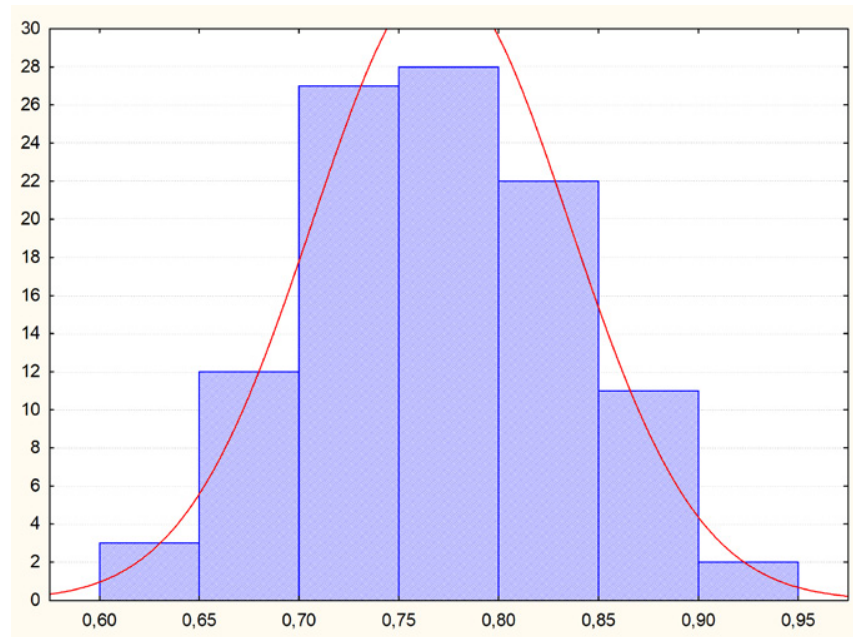

Fig. 1. The distribution of the logit-transformed data values of the soil cellulolytic activity.

Notes: the boundaries of categories are plotted on the $\mathrm{x}$ axis, \% (Category Boundary); the number of observations is plotted on the y axis, units.

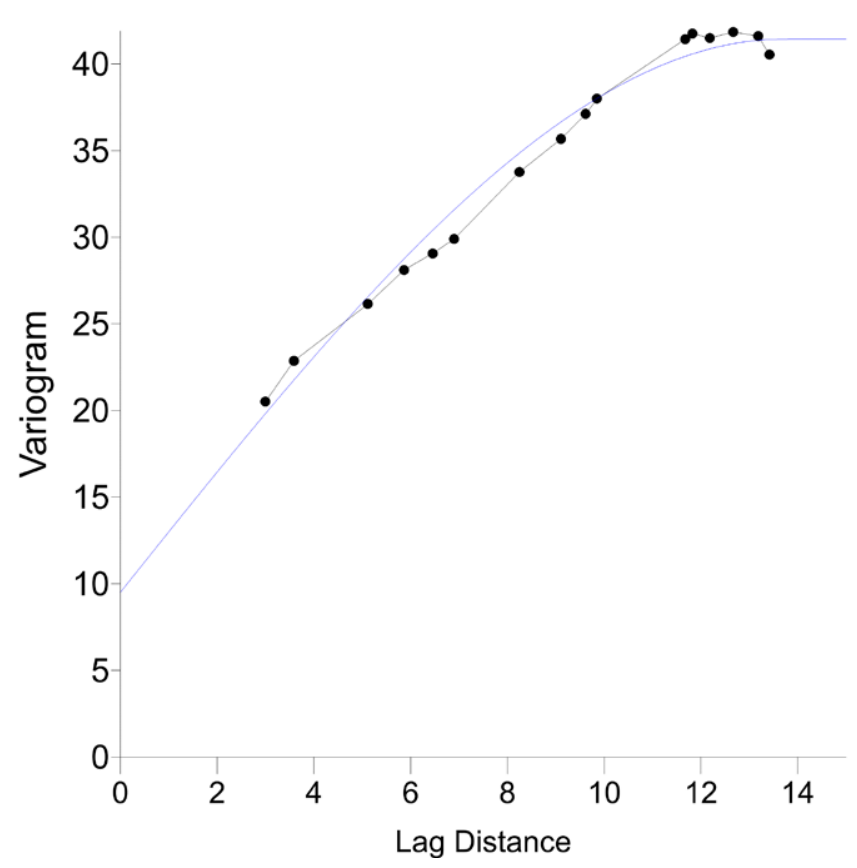

Fig. 2. Variogram of spatial distribution of soil cellulolytic activity Note: lag - the distance between pairs of sampling points $(\mathrm{m})$ is plotted on the $\mathrm{x}$ axis, semivariation is plotted on the $\mathrm{y}$ axis. The points are experimental data, the solid line is a spherical model.
$7 \times 15 \mathrm{~m}$. The distance between the sampling points was $3 \mathrm{~m}$. Accordingly, the dimensions of each test site were $18 \times 42 \mathrm{~m}$.

The soil body structure was studied by indicators of soil penetration resistance. The soil penetration resistance was studied in the field environment to a depth of up to 50 at $5 \mathrm{~cm}$ intervals. A hand penetrometer Eijkelkamp was used in the study (Medvedev, 2009; Medina et al., 2012; Zhukov, Zadorozhnaya, 2016, 2017; Zadorozhnaya, 2018). The average error of the measurement results of the device is $\pm 8 \%$. Soil penetration resistance was measured using a cone with a cross-section of $2 \mathrm{~cm}^{2}$ in each section of the test site.

Soil cellulolytic activity was studied using an application method (Berg et al., 1975; Zhukov, Lyadskaya, 2009; Tryfanova et al., 2013). Pieces of paper of the same weight was used for the experiment. It was a substrate for the decomposition of cellulolytic enzymes. Circles of filter paper were placed in a polyethylene mesh (cell size - 1.5 $\mathrm{mm}$ ) for the mechanical preservation of the material. The paper was inserted in the upper soil layer $0-10 \mathrm{~cm}$. Samples were dried and weighed after 15 days. A measure of soil cellulolytic activity is decrease in the weight of the substrate during the exposure.

The obtained data was submitted to logit transformation. This is to ensure that the variable can be described by a normal distribution. Data is presented as part of the initial weight. The data takes a value from 0 to 1 . For 1 , the weight of the unused filter paper is taken.

Logit transformation was performed according to the formula:

$$
\text { Cell }_{\log i t}=\ln \left(\frac{\text { Cell }}{1-\text { Cell }}\right) \text {, }
$$

where Cell ${ }_{\text {logit }}$ - log-transformed measure of soil cellulolytic activity, Cell - measure of soil cellulolytic activity.

Data can be used in geostatistical models after logit transformation. Methods of descriptive statistics used in statistical calculations. Geostatistical data analysis was used to determine the spatial dependence level of soil indicators - soil penetration resistance and cellulolytic activity (Webster, Oliver, 2007; Valbuena Calderon et al., 2008; Shahbazi et al., 2013). The spatial dependence level (SDL, spatial dependence level, spatial relation) is calculated by the formula:

$$
S D L=\frac{C_{0}}{C_{0}+C_{1}} \times 100,
$$

where $\mathrm{C}_{0}$ - nugget-effect, $\mathrm{C}_{1}$ - partial threshold.

Indicators $\mathrm{C}_{0}, \mathrm{C}_{1}$ and radius of influence $(\mathrm{R})$ are obtained on the basis of modeling variograms of indicators of spatial variability (Legendre, Fortin, 1989; Grunwald et al., 2001; Webster, Oliver, 2007).

The degree of relationship of spatial distribution of indicators of soil penetration resistance and cellulolytic activity was established using correlation analysis. 
Table 2. Spatial variation parameters of black soil penetration resistance.

\begin{tabular}{|c|c|c|c|c|c|c|}
\hline \multirow{2}{*}{$\begin{array}{l}\text { Distance from } \\
\text { the surface, } \mathrm{cm}\end{array}$} & \multicolumn{2}{|c|}{ Descriptive statistics } & \multicolumn{4}{|c|}{ Geostatistics } \\
\hline & $\mathrm{x} \pm \mathrm{SE}, \mathrm{MPa}$ & $\mathrm{CV}, \%$ & $\mathrm{C}_{0}$ & $\mathrm{C}_{1}$ & SDL, \% & $\mathbf{R}, \mathrm{M}$ \\
\hline $0-5$ & $4.25 \pm 0.15$ & 35.65 & 0.31 & 2.18 & 12.45 & 9.6 \\
\hline $5-10$ & $4.96 \pm 0.18$ & 36.51 & 0.44 & 3.10 & 12.43 & 9.3 \\
\hline $10-15$ & $4.93 \pm 0.18$ & 38.14 & 0.62 & 3.00 & 17.13 & 9.7 \\
\hline $15-20$ & $5.08 \pm 0.18$ & 35.44 & 0.80 & 2.70 & 22.86 & 9.8 \\
\hline $20-25$ & $5.26 \pm 0.15$ & 29.44 & 0.75 & 2.60 & 22.39 & 8.2 \\
\hline $25-30$ & $5.17 \pm 0.12$ & 24.48 & 0.11 & 1.70 & 6.08 & 5.6 \\
\hline $30-35$ & $4.97 \pm 0.11$ & 22.20 & 0.17 & 1.19 & 12.50 & 7.5 \\
\hline $35-40$ & $4.85 \pm 0.11$ & 23.57 & 0.18 & 1.35 & 11.76 & 7.9 \\
\hline $40-45$ & $4.87 \pm 0.11$ & 22.35 & 0.20 & 1.10 & 15.38 & 8.8 \\
\hline $45-50$ & $5.14 \pm 0.11$ & 22.15 & 0.29 & 1.00 & 22.48 & 7.1 \\
\hline $50-55$ & $5.25 \pm 0.12$ & 23.23 & 0.24 & 1.18 & 16.90 & 5.7 \\
\hline $55-60$ & $5.47 \pm 0.12$ & 22.98 & 0.60 & 1.50 & 28.57 & 7.2 \\
\hline $60-65$ & $5.83 \pm 0.13$ & 22.21 & 0.55 & 1.20 & 31.43 & 6.9 \\
\hline $65-70$ & $6.03 \pm 0.14$ & 24.39 & 1.72 & 2.20 & 43.88 & 5.4 \\
\hline $70-75$ & $6.22 \pm 0.15$ & 24.89 & 1.58 & 2.14 & 42.47 & 6.3 \\
\hline $75-80$ & $6.29 \pm 0.15$ & 24.77 & 1.58 & 2.15 & 42.36 & 5.7 \\
\hline $80-85$ & $6.25 \pm 0.15$ & 23.91 & 1.12 & 2.25 & 33.23 & 7.1 \\
\hline $85-90$ & $6.20 \pm 0.16$ & 27.06 & 1.09 & 1.79 & 37.85 & 5.3 \\
\hline $90-95$ & $6.23 \pm 0.17$ & 27.26 & 0.76 & 2.20 & 25.68 & 5.8 \\
\hline $95-100$ & $6.43 \pm 0.16$ & 24.73 & 0.78 & 1.71 & 31.33 & 5.2 \\
\hline $3 \mathrm{MPa}$ & $4.52 \pm 0.54$ & 122.26 & 1.9 & 26.52 & 6.69 & 9.1 \\
\hline
\end{tabular}

Notes: $\mathrm{x}$ - average values (MPa); $\mathrm{SE}$ - standard error; $\mathrm{CV}$ - variation coefficient (\%); $\mathrm{C}_{0}$ - nugget effect; $\mathrm{C}_{1}$ - partial threshold; SDL - spatial dependence level (\%); $\mathrm{R}$ - radius of influence $(\mathrm{m})$.

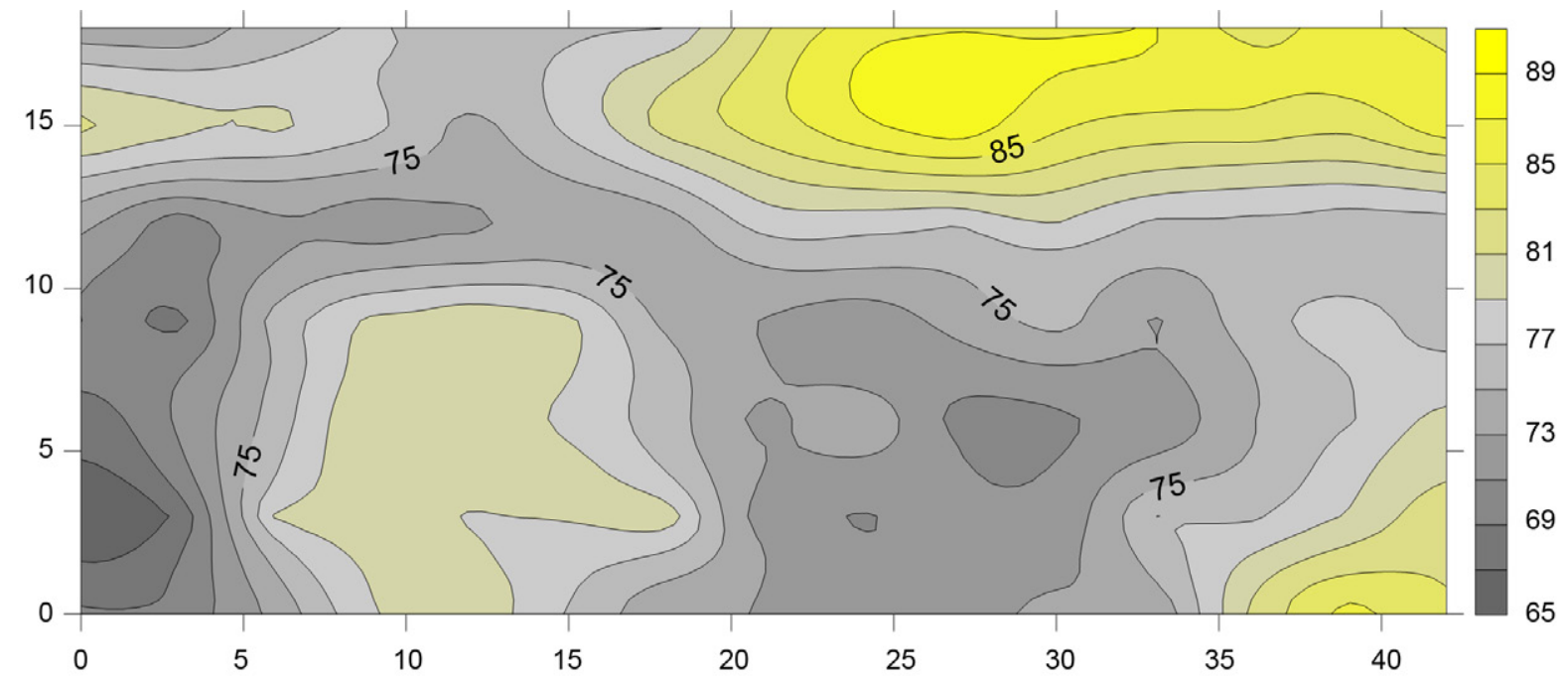

Fig. 3. Spatial variability of soil cellulolytic activity (in logit-transformed form).

\section{Results}

Parametrical statistical assessment is based on the assumption of normal distribution of random variables. Estimates of the confidence interval for a variable may be outside the natural range from 0 to 1 . Logit transformation allows us to obtain estimates that correspond to the nature of the quantity being studied. Analysis of the data in Figure 1 indicates that the distribution of the studied quantity corresponds to the normal law. The Kolmogorov-Smirnov test confirms this conclusion $(\mathrm{d}=0.073, \mathrm{p}<0.2)$. This allows us to use parametric statistical methods for further mathematical analysis (Table 1). 

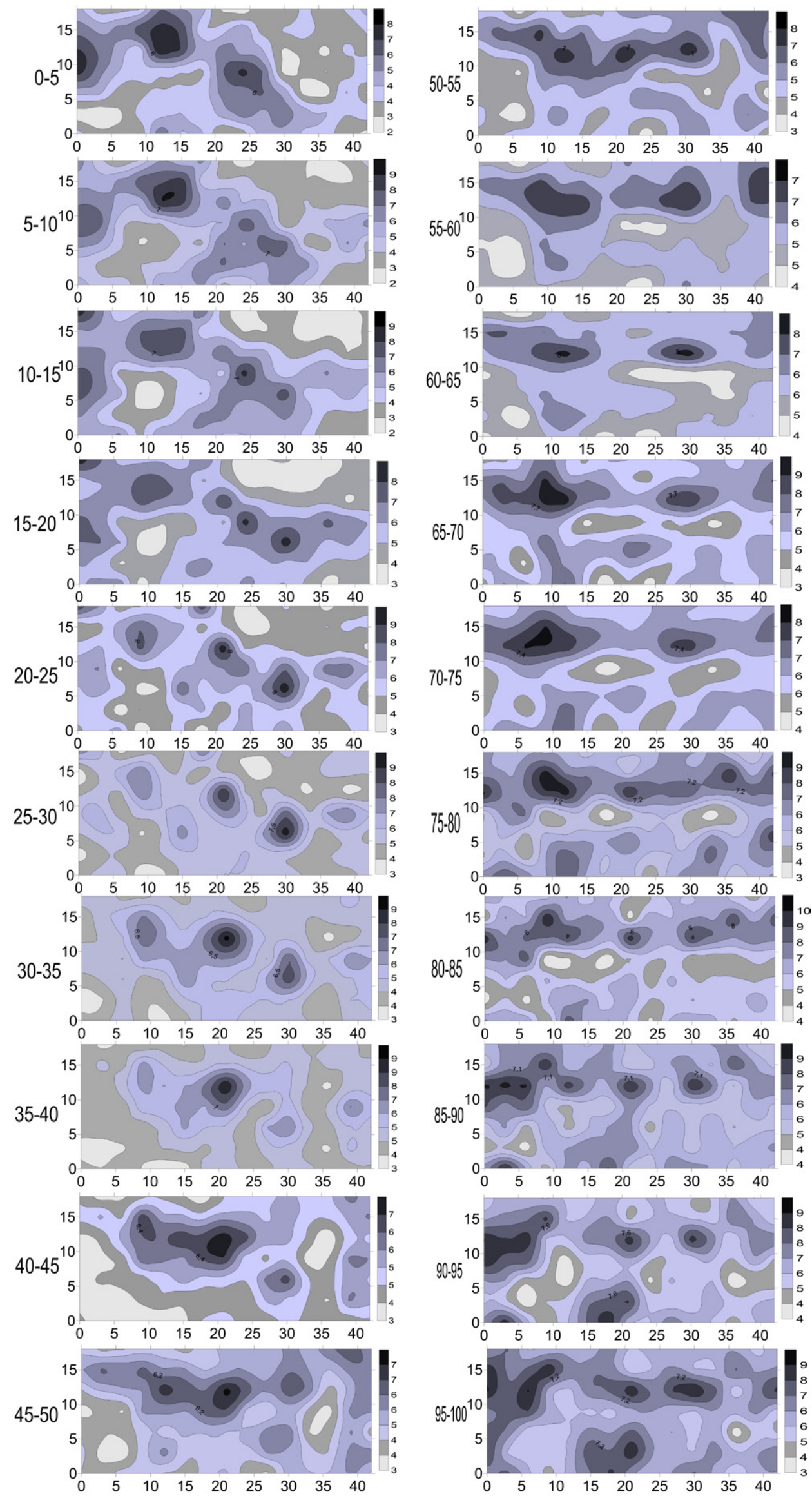

Fig. 4. Spatial distribution of values of soil penetration resistance in layers. 


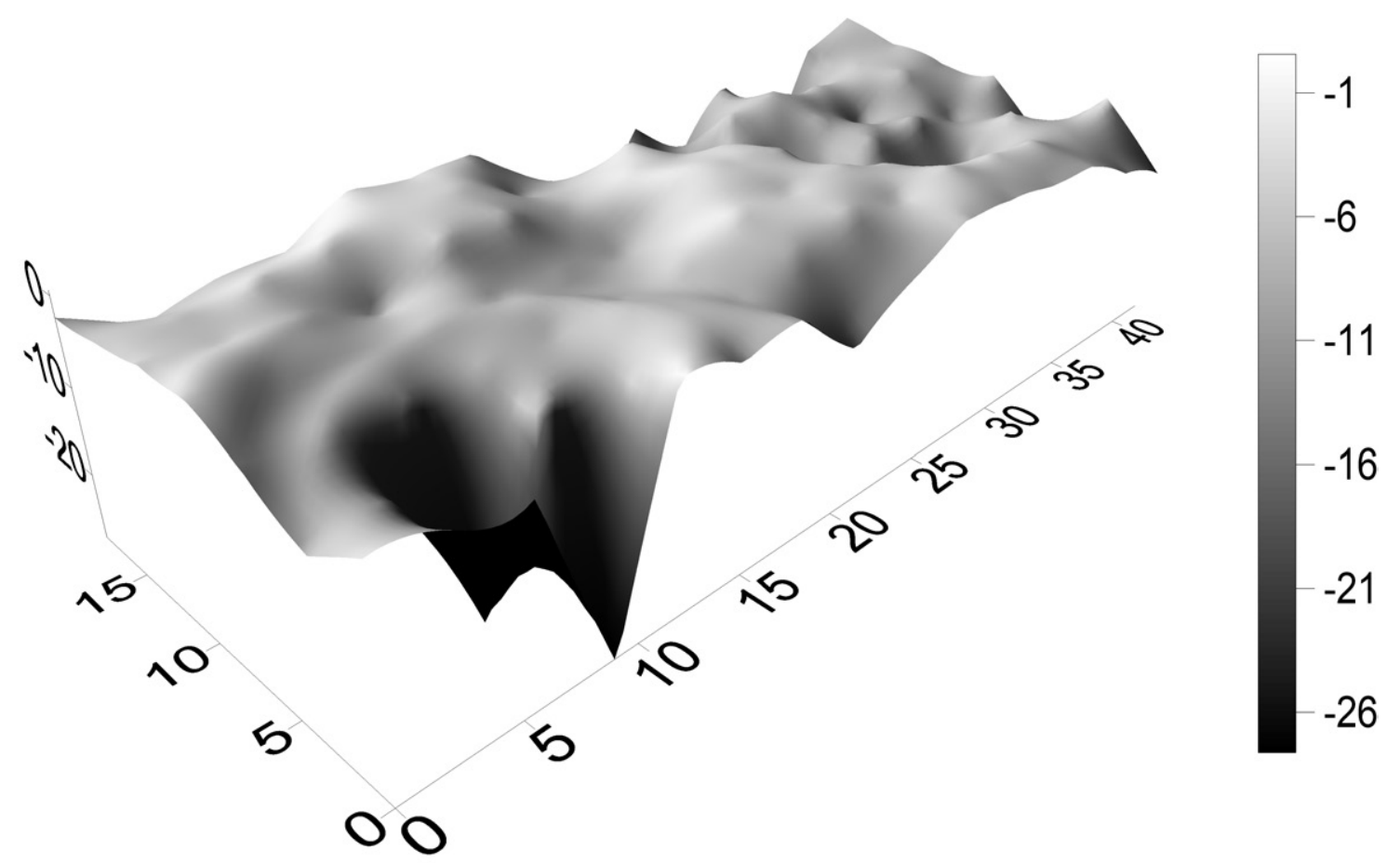

Fig. 5. Soil penetration resistance relief with a boundary criterion of $3 \mathrm{MPa}$.

The practical agreement of the mean and median values of cellulolytic activity also confirms the existence of a normal distribution law. The decomposition level of the substrate is in the range of $63-91 \% .76-78 \%$ of the substrate decomposed in $95 \%$ of cases. A spherical model was chosen to describe the spatial variation of cellulolytic activity (Fig. 2). The nugget effect of the variogram $\left(\mathrm{C}_{0}\right)$ is 9.5 , the partial threshold $\left(\mathrm{C}_{1}\right)$ is 41.43 . The calculation of the index SDL - the level of spatial dependence is based on this data (spatial dependence level $-100^{*} \mathrm{C}_{0} /($ $\left.\mathrm{C}_{0}+\mathrm{C}_{1}\right)$ ) (Cambardella et al, 1994; Diggle, Ribeiro, 2000). This indicator is $22.92 \%$, which corresponds to a significant spatial dependence.

The spatial variability map of soil cellulolytic activity is based on the data obtained (Fig. 3).

Visual assessment of the map suggests the presence of localities with high cellulolytic activity. These sites are quite large. The radius of these sites is on average equal to $13.93 \mathrm{~m}$. They form spatial structures. Cellulolytic activity values increase down the slope.

The soil penetration resistance increases with depth (Table $2)$. The variation coefficient is greatest in the upper layers of soil profile $(0-25 \mathrm{~cm})$. The spatial dependence level of the data is high in the upper half of the profile $(0-55 \mathrm{~cm})$ and has average values in the lower half.

Geostatistical data provide an opportunity to build maps of the spatial distribution of soil penetration resistance in layers (Fig. 4).

We can observe on the maps that the soil studied has a spatial structure. More solid areas are combined into spatial structures - elements of heterogeneity. These structures are found
Table 3. Correlation between the distribution of soil penetration resistance values and cellulolytic activity of the soil $(\mathrm{N}=105)$.

\begin{tabular}{|c|c|}
\hline Layers depth, cm & Correlation coefficient \\
\hline $0-5$ & $-0.24^{\star}$ \\
\hline $5-10$ & $-0.46^{\star}$ \\
\hline $10-15$ & $-0.58^{\star}$ \\
\hline $15-20$ & $-0.49^{\star}$ \\
\hline $20-25$ & $-0.40^{\star}$ \\
\hline $25-30$ & $-0.26^{\star}$ \\
\hline $30-35$ & -0.04 \\
\hline $35-40$ & 0.03 \\
\hline $40-45$ & 0.17 \\
\hline $45-50$ & $0.25^{\star}$ \\
\hline $50-55$ & $0.22^{\star}$ \\
\hline $55-60$ & $0,27^{\star}$ \\
\hline $60-65$ & $0.27^{\star}$ \\
\hline $65-70$ & 0.08 \\
\hline $70-75$ & 0.10 \\
\hline $75-80$ & 0.05 \\
\hline $80-85$ & -0.04 \\
\hline $85-90$ & -0.13 \\
\hline $90-95$ & $-0.21^{\star}$ \\
\hline $95-100$ & -0.17 \\
\hline $3 \mathrm{MPa}$ & $-0.30^{\star}$ \\
\hline & \\
\hline
\end{tabular}

Note: ${ }^{*}-$ significant correlations are noted at $\mathrm{p}<0.05$ (Marked correlations are significant at $\mathrm{p}<0.05$ ). 
in less solid soil material. These elements of heterogeneity are similar to truncated cones in a three-dimensional image. Their radius ranges from $9.8 \mathrm{~m}$ to $5.2 \mathrm{~m}$ and decreases with depth (Table 2). The soil penetration resistance value of $3 \mathrm{MPa}$ is found on average to a depth of $4.52 \mathrm{~cm}$ and is highly variable $(\mathrm{CV}=122.26 \%)$. The outlines of spatial structures are visible on the three-dimensional image of the subsoil relief (Fig. 5).

The relationship between soil heterogeneity and cellulolytic activity of the soil was found during correlation analysis (Table $3)$.

A significant positive correlation is observed in layers 45 $50 \ldots 60-65 \mathrm{~cm}$ below the surface. Cellulolytic activity has a negative correlation with soil penetration resistance in layers $0-5$... 25-30, 90-95 cm. Also, negative correlation is observed with the spatial distribution of the soil penetration resistance value of $3 \mathrm{MPa}$.

\section{Discussion}

Soil heterogeneity is an inalienable property of the soil and is currently an object of active study (Salvador-Blanes et al., 2006; Soracco et al., 2010; Medvedev, 2013). Soil penetration resistance is an informative indicator of heterogeneity. Changes in penetration resistance correlate with a large number of soil indicators that are important for fertility. In addition, a large amount of data can be collected using a penetrometer in a relatively short period of time. These data are important for building geostatistical models. Our study found that the cellulolytic activity of black soil is closely related to its penetration resistance. The negative correlation between the studied parameters in the upper part of the soil profile indicates that cellulolytic activity is higher where the penetration resistance is less. This is completely logical because penetration resistance depends on the presence of organic matter in the soil (Grunwald et al., 2001; Medina et al., 2012). The higher the organic content, the lower the penetration resistance. At the same time, microorganisms feed on the organic matter in the soil, thereby decomposing it. Therefore, increase in the amount of organic matter increases their activity. However, a positive correlation was found between the penetration resistance indicator in the middle part of the soil profile and cellulolytic activity. Following our method, cellulose was placed in the soil layer $0-10 \mathrm{~cm}$ from the surface. The results reflect a significant correlation of soil conditions at different depths. We assume that this relationship is realized through the flows of soil moisture. The increasing soil penetration resistance at the depth of 45 to 65 $\mathrm{cm}$ creates a barrier to water and improves the conditions for the existence of microorganisms. As a result, in areas where the soil penetration resistance at this depth is higher, the soil has a higher biological activity. Our assumptions are confirmed by correlation with the position of the hardness barrier of $3 \mathrm{MPa}$. According to researchers, a penetration resistance of $3 \mathrm{MPa}$ is the limit of penetration of the root systems of most plants. This position is disputed by other authors. The limit of penetration varies in the data of different authors from 0.8 to $5 \mathrm{MPa}$ (Faechner et al., 2000; Bathke et al., 1992). However, the significant relationship established with cellulolytic activity of the soil confirms the importance of this indicator for the formation of ecological conditions of the soil. Similar results were obtained by us earlier in a study of the cellulolytic activity of alluvial sod forest soil, which is formed on sandy sediments (Tryfanova et al., 2013). The cellulolytic activity of sandy soil is significantly lower than that of black soil. However, we observed an ecological relationship between the variation of soil penetration resistance at different depths and cellulolytic activity.

The results of our research demonstrate the great importance of spatial organization of the soil for the formation of its properties. A relationship of the soil structure with the spatial structure of other ecosystem components exists. As established, these ecosystem components are microorganisms and the plant community (Zadorozhnaya et al., 2018). The patterns revealed constitute a reason to describe the discovered morphological elements of the soil by the term soil bodies. These soil bodies are a form of existence of soil in the ecosystem and are characterized by the presence of direct ecological links with ecosystem components.

\section{Conclusion}

The flow of biological processes in the soil is closely related to its spatial heterogeneity on the basis of penetration resistance.

Black soil cellulolytic activity has a high level of spatial dependence. Sites of the same type are combined and form the spatial structure of the experimental area. The radius of sites with increased cellulolytic activity is on average equal to 13.93 m.

Indicators of soil penetration resistance have a high spatial dependence from the surface to a depth of $55 \mathrm{~cm}$. The average level of spatial dependence is characteristic of the lower half of the soil profile (60-100 $\mathrm{cm}$ from the surface). The greatest variability of penetration resistance indicators was recorded in the upper layers of the soil profile $(0-25 \mathrm{~cm}$ deep). Geostatistical modeling allows one to find three-dimensional structures of spatial heterogeneity. These elements of heterogeneity have a radius of 9.8 to $5.2 \mathrm{~m}$. Their size decreases with depth.

Indicators of cellulolytic activity demonstrate a significant negative relationship with increased penetration resistance in layers $0-5$... 25-30, 90-95 cm from the surface. Sites of soil with high penetration resistance in layers $45-50 \ldots 60-65 \mathrm{~cm}$ from the surface are characterized by high cellulolytic activity of the black soil surface layer.

\section{References}

Andrusevych, E.V. (2014). Ecological space of the sod-lithogenic soils on the red-brown clays animal community. Gruntoznavstvo, 15, 1-2. DOI: $10.15421 / 041411$.

Andrusevych, E.V. \& Shtirts Yu.A. (2014). Ecological diversity of vegetation on lithogenic soil in the reclamation land of the Nicopol manganese ore basin. Industrial Botany, 14, 115-127.

Bathke, G.R., Cassel, D.K., Hargrove, W.L. \& Porter P.M. (1992). Modification of soil physical properties and growth response. Soil Sci., 154, 316-329.

Berg, B., Karenlampi, L. \& Veum A.K. (1975). Comparisons of decomposition rates measured by means of cellulose. In F.E. Wielgolaski (Ed.), Fennoscandian tundra ecosystems. Part 1. Plants and microorganisms (pp. 261-267). Berlin: Springer.

Cambardella, C.A., Moorman, T.B., Parkin, T.B., Karlen, D.L., Novak, J.M., Turco, R.F. \& Konopka A.E. (1994). Field scale variability of soil properties in central Iowa soils. Soil Sci. Soc. Am. J., 58, 1501-1511. DOI: 10.2136/sssaj1994.03615995005800050033x. 
Diggle, P.J. \& Ribeiro J.R. (2000). Model based geostatistics. Sao Paulo: Associacao Brasileira de Estatistica.

Faechner, T., Pyrcz, M.J. \& Deutsch C.V. (2000). Soil remediation decision making in presence of uncertainty in crop yield response. Geoderma, 97, 21-38. DOI: 10.1016/S0016-7061(00)00024-0.

Grunwald, S., McSweeney, K., Rooney, D.J. \& Lowery B. (2001). Soil layer models created with profile cone penetrometer data. Geoderma, 103(1-2), 181-201. DOI: 10.1016/S0016-7061(01)00076-3.

Kramarenko, S.S, Kunakh, O.N., Zhukov, A.V. \& Andrusevich E.V. (2014) Analysis of the spatial distribution patterns of the land snail populations: a geostatistic method approach. The Bulletin of the Russian Far East Malacological Society, 18, 5-40.

Kunakh, O.N., Kramarenko, S.S., Zhukov, A.V., Zadorozhnaya, G.A. \& Kramarenko A.S. (2018). Intra-population spatial structure of the land snail Vallonia pulchella (Müller, 1774) (Gastropoda; Pulmonata; Valloniidae). Ruthenica, 28 (3), 91-99. http: www.ruthenica.com

Latter, P.M. \& Harrison A.F. (1988). Decomposition of cellulose in relation to soil properties and plant growth. In A.F. Harrison, P.M. Latter \& D.W.H. Walton (Eds.), Cotton strip assay: an index of decomposition in soils (pp. 68-71). Grange-over-Sands: Institute of Terrestrial Ecology.

Legendre, P. \& Fortin M.J. (1989). Spatial pattern and ecological analysis. Vegetatio, 80, 107-138. https://www.jstor.org/stable/20038425

Medina, C., Camacho-Tamayo, J.H. \& Cortés C.A. (2012). Soil penetration resistance analysis by multivariate and geostatistical methods. Engenharia Agrícola, 32(1), 91-101. DOI: 10.1590/S0100-69162012000100010.

Medvedev, V.V. (2009). Soild and soildgram in research on the treatment of soil. Pochvovedenie, 3, 325-336.

Medvedev, V.V. (2013). Time and spatial heterogenization of soil plouger up. Gruntoznavstvo, 14 (1-2), 5-22.

Myšák, J., Horsák, M., Svobodová, E. \& Cernohorsky N. (2013). Small-scale distribution of terrestrial snails: patterns of species richness and abundance related to area. J. Molluscan Stud., 79(2), 118-127. DOI: 10.1093/ mollus/eyt002.

Salvador-Blanes, S., Cornu, S., Couturier, A., King, D. \& Macaire J.J. (2006) Morphological and geochemical properties of soil accumulated in hedge-induced terraces in the Massif Central, France. Soil Till. Res. 85(1-2), 62-77. DOI: $10.1016 /$ j.still.2004.12.008.

Shahbazi, F., Ali, N. \& Najaf N. (2013). Geostatistical analysis for predicting soil biological maps under different scenarios of land use Eur. J. Soil Biol., 55, 20-27. DOI: 10.1016/j.ejsobi.2012.10.009.
Soracco, C.G., Lozano, L.A., Sarli, G.O., Gelati, P.R. \& Filgueira R.R. (2010), Anisotropy of saturated hydraulic conductivity in a soil under conservation and no-till treatments. Soil Till. Res., 109, 18-22. DOI: 10.1016/j. still.2010.03.013.

Swift, M.J., Heal, O.W. \& Anderson J.M. (1979). Decomposition in terrestrial ecosystems. Oxford: Blackwell Scientific.

Tryfanova, M., Zadorozhnaya, G. \& Zhukova J. (2014). Gray heron colony impact on soil cellulolytic activity. Visnyk of Lviv University, Biological Series, 65, 245- 254.

Valbuena Calderon, C.A., Martines, L.J. \& Giraldo Henao R. (2008). Spatial variability of soil properties and yield relationship in a mango crop (Mangifera indica L.). Revista Brasileira de Fruticultura, 30(4), 1146-1151. DOI: 10.1590/S0100-29452008000400049.

Webster, R. \& Oliver M.A. (2007). Geostatistics for environmental scientists. Hoboken: John Wiley \& Sons.

Zadorozhnaya, G.A. (2018). Spatiotemporal dynamics of soil penetration resistance of recultivated soil. Ekológia (Bratislava), 37(3), 82-89. DOI 10.2478/eko-2018-0008.

Zadorozhnaya, G.A. \& Andrusevych K. (2018). Recultivated soil heterogenety: ecological aspect. Applied Biotechnology in Mining: Proceedings of the International Conference (p. 53). Dnipro, April 25-27, 2018 Dnipro: National Technical University "Dnipro Polytechnic".

Zadorozhnaya, G.A., Andrusevych, K.V. \& Zhukov O.V. (2018). Soil heterogeneity after recultivation: ecological aspect. Folia Oecologica, 45(1), 46-52. DOI: 10.2478/foecol-2018-0005.

Zhukov, A.V. \& Lyadskaya I.V. (2009). Cellulosolytic activity of technosemas in the experimental area of land reclamation caused by the mining industry. Bulletin of Donetsk National University, Series A: Natural Sciences, 2, 286-290.

Zhukov, A.V. \& Zadorozhnaya G.A. (2015). The phenomenon of soil ectomorphs. In $V$ All Ukrainian Congress of Ecologists with International Participation (Ecology-2015), Collection of scientific works (p. 190). Vinnitsa: TOV «Nilan-LDT».

Zhukov, A.V. \& Zadorozhnaya G.A. (2016). Spatial heterogeneity of mechanical impedance of atypical chernozem: the ecological aproach. Ekológia (Bratislava), 35(3), 263-278. DOI: 10.1515/eko-2016-0021.

Zhukov, A.V. \& Zadorozhnaya G.A. (2017). The dynamics of the replantozems spatial heterogeneity. Principles of the Ecology, 6, 1(12), $226-237$. 